\title{
Fishing for Oil: Natural-Resource Management between the United States and Maritime East Asia in the $1970 \mathrm{~s}$
}

\author{
Kuan-Jen Chen \\ Isaac Newton Trust Postdoctoral Research Associate, Faculty of Asian and \\ Middle Eastern Studies, University of Cambridge, UK \\ kjc46@cam.ac.uk
}

\begin{abstract}
The possibility of oil reserves under the seabed of the East China Sea created competition between Japan, South Korea, and Taiwan to claim ownership of these natural resources. The dispute marked the start of international cooperation in maritime East Asia and introduced the United States into this power game due to its exploration techniques and financial power. While Taibei, Tokyo, and Seoul put sovereignty-related disputes aside in an attempt to explore resources jointly, the change in international politics in East Asia and Washington's perception of the western Pacific rim led to the failure of cooperation. This article argues that this international power game over natural resources management epitomized the dynamic politics between the United States and its East Asian allies. The roles of sovereignty, local interests, and U.S. international security created a dynamic scenario revealing how oil reserves were never the issue, but instead the embodiment of the actual concerns of these players behind their diplomatic language. Situating the 1970s oil exploration in the context of the Cold War, this article provides a historical lens to understand the contours of the shifting geopolitical structure in maritime East Asia.
\end{abstract}

\section{Keywords}

Maritime East Asia - oil exploration - Senkakus - Diaoyutai - Continental Shelf - U.S. maritime policy 
In 1970, U.S. President Richard M. Nixon announced a "New Ocean Policy" "The United States as a major maritime power and a leader in ocean technology to unlock the riches of the ocean," he proclaimed, "has a special responsibility to move this effort forward." The "riches of the ocean" included oil, which was crucial to military, heavy, and light industries for both developing and developed countries. The New Ocean Policy revealed the Nixon administration's ambition to play a leading role in the future of maritime natural resource management. However, was the only U.S. concern the potential profit obtainable from the oil reserves beneath the ocean floor? If we shift our historical lens to Cold War East Asia, we can find not only that the relationships between U.S. natural-resource management and its geopolitical concerns were connected inextricably, but also that the current international disputes over the ownership of the Diaoyu/Senkaku islands and underwater natural resources are not recent phenomena, but the result of a historical evolution.

After experiencing the 1950-1953 Korean War and the 1954-1955 First Taiwan Strait Crisis, the United States reappraised the geostrategic value of maritime space and gradually adopted a sea-oriented strategic thinking in the defense of East Asia. ${ }^{2}$ Maritime space, for decision makers in Washington, served as a geographical platform to project U.S. military power, but also functioned as a link tying its allies together to maintain Pax Americana against Communists across the ocean. This article defines U.S. geostrategic contours in the western Pacific rim as "maritime East Asia."

While the United States-led hub-and-spoke alliance closely bonded its local partners-Japan, South Korea, and Taiwan-together, the competing claims over the underwater natural resources made the international politics volatile in maritime East Asia. ${ }^{3}$ The high probability of oil reserves under the seabed of the East China Sea that the 1969 Emery report identified brought the United States, with its cutting-edge exploration techniques and financial power, to

1 Richard M. Nixon, "Statement about United States Ocean Policy," 23 May 1970, Chapter Six: Oceans Policy, Foreign Relations of the United States, 1969-1976, Volume E-1, Documents on Global Issues, 1969-1972, https://2001-2009.state.gov/r/pa/ho/frus/nixon/e1/53194.htm (accessed 18 October 2019).

2 In Kuan-jen Chen's dissertation, he analyzes the shifting contours of 1950s postwar U.S. naval policy in the western Pacific. Kuan-jen Chen, "U.S. Maritime Policy in Cold War East Asia, 1945-1979," unpublished Ph.D. dissertation, University of Cambridge, Cambridge, UK, 2019, pp. 149-222.

3 Regarding hub-and-spoke alliance, see Victor Cha, Powerplay: The Origins of the American Alliance System in Asia (Princeton, NJ: Princeton University Press, 2016); Gilford John Ikenberry, "American Hegemony and East Asian Order," Australian Journal of International Affairs 58, no. 3 (September 2004):353-67. 
cooperate with Japan, South Korea, and Taiwan. But it also created competition between these countries to claim ownership of these natural resources.

While there is abundant scholarship on the question of the ownership of the Diaoyudao/Senkakus resulting from the oil exploration project in maritime East Asia, scholars have paid little attention to the political language behind international oil cooperation and the role the United States played in the context of the Cold War. ${ }^{4}$ Drawing on archival documents from Britain, Japan, South Korea, Taiwan, and the United States, this article first examines the reason behind the disputes in the East China Sea. It not only analyzes how Seoul, Taibei, and Tokyo held questions about the ownership of the disputed islands in abeyance in an attempt to explore oil resources jointly, but also examines the influence sovereignty and local interests between these countries had on these international cooperation projects in the 1970s.

Second, this article demonstrates that the volatile international situation and the changing nature of great-power politics inevitably resulted in the failure of these projects. It argues that the changing international political structure in East Asia in the 1970s led the United States to alter its perception of the western Pacific. For decision makers in Washington, the sea temporarily ceased to be a strategic space for containing the People's Republic of China (PRC) and instead became a platform for signalling goodwill during the course of the Beijing-Washington rapprochement that had begun with Nixon's visit to China in February 1970. As a corollary, the United States actively partook in a chess game over oil exploration projects and its involvements accelerated the breakdown of all the progress that Japan, South Korea, and Taiwan had achieved.

Finally, this article argues that this chess game over oil exploration embodied the shifting contour of international politics in East Asia. The signing of Japan-Korea oil exploration agreements relocated Taiwan from center to periphery in the search for new energy sources. Taiwan lost not only its ticket to the negotiating table of oil exploration in maritime East Asia, but also its voices in international political arena. The oil exploration projects in maritime

4 There is well-trodden scholarship on the issue of the Diaoyudao/Senkakus which beautifully examines the origins of these disputed islands. See Jean-Mark Blanchard, "The US Role in the Sino-Japanese Dispute over the Diaoyu (Senkaku) Islands, 1945-1971," China Quarterly 161 (March 2000): 95-123; Robert Eldridge, The Origins of U.S. Policy in the East China Sea Islands Dispute: Okinawa's Reversion and the Senkaku Islands (Abingdon, Oxon, UK: Routledge, 2014); Robert Eldridge, The Origins of the Bilateral Okinawa Problem: Okinawa in Postwar U.S.-Japan Relations, 1945-1952 (New York: Garland, 2001); Shannon McCune, Islands in Conflict in East Asian Waters (Hong Kong: Asian Research Service, 1984); Tao Cheng, "The Sino-Japanese Dispute Over the Tiao-yu-tai (Senkaku) Islands and the Law of Territorial Acquisition," Virginia Journal of International Law 14, no. 2 (Winter 1974): 221-66. 
East Asia revealed the actual concerns of these players behind their diplomatic language; under these circumstances, the reserves and whereabouts of oil beneath the continental shelf of the East China Sea were never the issue. In short, this research reintroduces the oil exploration projects of the western Pacific into the context of Cold War history to provide the necessary historical lens to understand the contours of the shifting geopolitical structure in 1970s maritime East Asia.

Owing to advances in technology and the global need for energy, the international community began to recognize the significance of oil reserves under the continental shelf at the end of the 196os. On the recommendation of the United Nations Economic Commission for Asia and the Far East, the United Nations began to survey potential natural resources of the continental shelf at the end of the 196os. Japan, South Korea, and Taiwan, formally began surveying natural resources in the Pohang area off the east coast of the Korean peninsula and north western offshore Taiwan in $1966 .{ }^{5}$ The international joint oil investigation also brought the United States, with its cutting-edge exploration techniques and financial power, to the geopolitical platform of maritime East Asia. Following an investigation of the East China Sea, the investigation team produced the Emery Report that indicated the shallow sea floor between Japan and Taiwan, as well as under the Yellow Sea, likely contained some of the largest oil reserves in the world. ${ }^{6}$ This optimistic assumption raised the curtain for both international cooperation and conflict in maritime East Asia.

The potentially abundant oil reserves under the continental shelf in the East China Sea became a point of contention between Japan, South Korea, and Taiwan due to the definition of ownership of the continental shelf. Both South Korea and Taiwan, who are adjacent to the Asian continent (while the Nationalist government lost control of mainland China after 1949, it still asserted its legal control over the whole of mainland China), considered that the ownership of natural resources beneath the continental shelf should be the natural prolongation of their country's land territory. ${ }^{7}$ Conversely, Japan, as an island

5 Report on offshore geophysical survey project for evaluation of petroleum potentialities in the Pohang Area (East Coast of Korea)/Report on visit to the Republic of China (Taiwan), 18 May 1966/30 June 1966, S-0175-0004-03, Offshore prospecting for mineral resources-AFE $(111-3)$, United Nations Archives and Records Management Section [hereafter UnARMs], New York, NY.

6 Kenneth Emery, et al., "Geological Structure and Some Water Characteristics of the East China Sea and Yellow Sea." Technical Bulletin 2 (1969): 3-43.

7 The process of conclusion, 26 February 1974, 604.23/oo11, Korea-Japan Mutual Exploration Zone Overlapped Our Zone v [KJMEz], Diplomatic Documents [DD], Archive of Institute of Modern History [hereafter AIM H], Academia Sinica, Taibei, Taiwan. Guoxing Ji, "SinoJapanese Jurisdictional Delimitation in East China Sea," in Maritime Boundary Dispute, 
country, insisted that the boundary of the continental shelf should be the median line indicated in the $195^{8}$ Convention on the Continental Shelf- "every point of which is equidistant from the nearest points of the baselines from which the breadth of the territorial sea of each State is measured."8 These differing definitions of the continental shelf planted the seeds for the forthcoming conflict in maritime East Asia.

Both Japan and South Korea appeared to be enthusiastic in asserting their rights in the East China Sea. In 1969, Satō Eisaku, the prime minister of Japan, announced that his administration would allocate $\$ 580$, ooo during the following fiscal year for further research because the Japanese government believed in the possibility of discovering new oil reserves in the East China Sea and that these crude-oil deposits could transform Japan into a major oil supplier. ${ }^{9}$ To achieve this goal, Tokyo granted four Japanese oil companies concessions near Japan and these companies contracted with U.S. oil companies for future exploration (Figure 1). ${ }^{10}$ Meanwhile, South Korea also took the same active approach toward oil exploration; the Pak Chŏng-hŭi administration not only announced its claim to the natural resources of the seabed in the form of a domestic law that established seven seabed mining blocks, but also signed contracts with American oil companies, such as Gulf Oil Company, to explore for natural resources in 1970 (Figure 1). ${ }^{11}$

If we shift our attention to Taiwan, we can find that the Japanese and South Korean claims drove Taiwan to take some measures. Due to the limited infrastructure of exploration technologies in Taiwan, cooperating with foreign investors would be essential for oil exploration. These concerns pushed Taibei in October 1970 to announce a Regulation on Oil Exploration in the Maritime Area as a basis for international cooperation with U.S. oil companies. Meanwhile, Taiwan also officially claimed five offshore petroleum exploration

Settlement Process, and the Law of the Sea, Seoung-Yong Hong and Jon M. Van Dyke, eds. (Leiden, Netherlands: Martinus Nijhoff Publishers, 2009), 88.

8 "Convention on the Continental Shelf," Socioeconomic Data and Applications Center, http://sedac.ciesin.columbia.edu/entri/texts/continental.shelf.1958.html (accessed on 18 October 2019).

9 "Deposit is sought in East China Sea: Oil is sought in the Far East," New York Times, 17 May 1969, pp. 43, 51; "Japan will press efforts to exploit major oil find," New York Times, 1 September 1969, p. 2.

10 Choon-Ho Park, "Oil Under Troubled Waters: The Northeast Asia Sea-Bed Controversy," Harvard International Law Journal 14, no. 2 (Spring 1973): 218-20.

11 Hee Kwon Park, The Law of the Sea and Northeast Asia: A Challenge for Cooperation (Leiden, Netherlands: Martinus Nijhoff, 200o), 38-39; The summary of process of KoreaJapan joint exploration for oil in the East China Sea, 6 November 1972, 604.23/oo11, KJMEZ, DD, AIMH. 


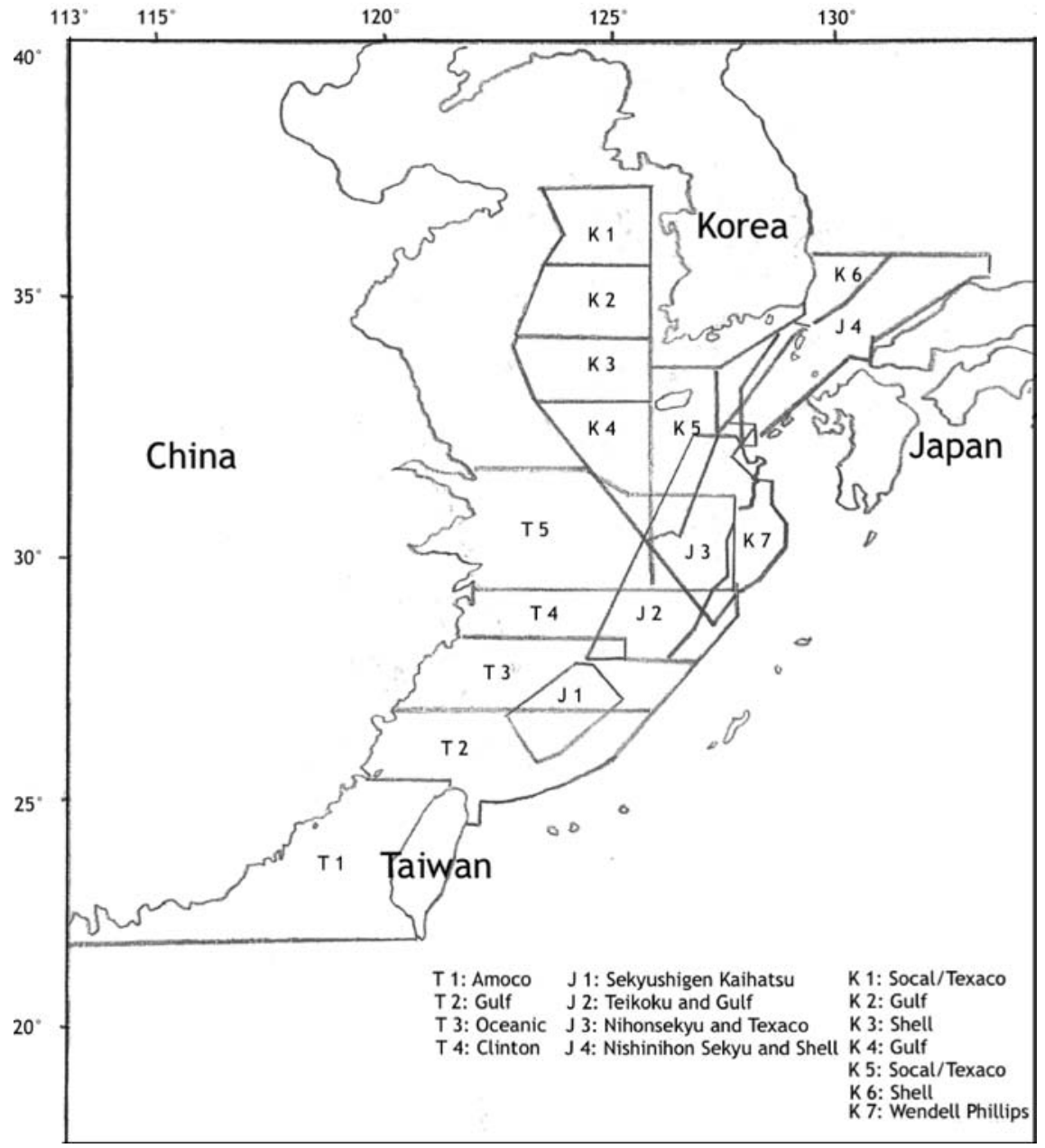

FIGURE 1 The Map for Korea's and Taiwan's mining Zones and Japan's Concession SOURCE: OUR OIL EXPLORATION ZONES OVERLAPPING KOREA'S AND JAPAN'S AREAS, A303000000B/0058/431.6/0029, MOE [MARITIME OIL EXPLORATION], DD [Diplomatic DOCUMENTS], NATIONAL ARChives ADMinistration, TAIBEI, TAIWAN.

zones in an attempt to strengthen its legal stance toward Japan and South Korea in consideration of potential conflicts (Figure 1). ${ }^{12}$ Similar to Japan and

12 Hong-zhi Ceng, "Woguo haiyu shiyou kuangqu zhi huali ji waizi canyu hezuo tanyou" ["The Delimitation of Taiwan's Maritime Oil Mining Zones and Cooperation Survey with Foreign Investments"], Kuangye [Mining and Metallurgy] 56, no. 3(September 2012): 11; Shin Kawashima, "The Origins of the Senkaku/Diaoyu Islands Issue," Asia-Pacific Review 20, no. 2 (2013): 130. "Yesterday, the Ministry of Foreign Affairs [MOFA] seriously proclaimed that we have the right to explore the natural resources of the continental shelf," 
South Korea, Taiwan also contracted with U.S. companies to explore the natural resources of the seabed, such as Amoco in Zone I, Gulf Oil Company in Zone II, Oceanic in Zone III, and Clinton Oil Company in Zone IV. ${ }^{13}$ As seen from Figure 1, these countries' concessions and mining zones overlapped with each other, which created tensions between Japan, South Korea, and Taiwan. ${ }^{14}$

Among these overlapping zones, the most controversial was the area near the Diaoyudao/Senkakus. Taibei asserted its right to explore oil in the area near the Diaoyudao/Senkakus because that continental shelf was a prolongation from mainland China where the Nationalist government still asserted its legal domain after its loss of control over mainland China in 1949. Taiwan's claim to its offshore petroleum exploration zones in the East China Sea attracted Japan's attention because Tokyo regarded the Diaoyudao/Senkakus as its territory and claimed the right to explore its undersea natural resources. ${ }^{15}$ In the Japanese Diet, on 7 December 1970, when Itō Sōsukemaru, the member of the House of Representatives, questioned Aichi Kiichi, the minister of foreign affairs of Japan, about Taiwan's current claim to the natural resources near the Diaoyudao/Senkakus, Aichi was blunt. "No matter what the plan is," he staunchly proclaimed, "the Japanese government cannot recognize it because this issue cannot unilaterally be claimed by one side."16 Japan's insistence on the ownership of the Diaoyudao/Senkakus deepened its distrust of Taiwan and complicated the future international joint projects.

While Taiwan attempted to negotiate these issues with neighboring countries in accordance with the 1958 Convention on the Continental Shelf, it found itself in a difficult position because neither Japan nor South Korea was a signatory and therefore this document could not provide a paradigm for negotiation in maritime East Asia. ${ }^{17}$ To break this deadlock, Chiang Kai-shek, the highest

Central Daily News, 15 February 1974; Letter from the Ministry of Economic Affairs to MOFA, 25 July 1970, 602.6/ooo1, Overlapping of the Republic of China (Rос) and the Republic of Korea (ROK) Continental Shelf, DD, AIMH.

13 Report, 4 October 1970, 604.23/0007, Maritime Oil Exploration [MOE], DD, AIMH.

14 Eldridge, The Origins of U.S. Policy in the East China Sea Islands Disputes, p. 115.

15 The United States occupied the Diaoyudao/Senkakus following the end of World War II and it planned to return these islands to Japan in 1972 in accordance with the [Richard M.] Nixon-Satō [Eisaku] Joint Statement. See Telegramme from Roc Embassy in Japan to MOFA, 22 August 1970, 604.23/ooo6, MOE, DD, AIMH.

16 "The record of Cabinet Committee No. 2, The House of Representatives, the $64^{\text {th }}$ National Diet," 7 December 1970, http://kokkai.ndl.go.jp/SENTAKU/syugiin/o64/oo2o/o6412070o 20002.pdf (accessed 2 June 2019).

17 The brief report of the current development of maritime oil exploration, 2o November 1970, 604.23/0007, moE, DD, AIMH; ROC mofa Press Release No. 139, 21 August 1970, 604.23/0006, ibid. 
decision maker in Taibei, changed his stance on the issue of the Diaoyu/ Senkaku islands. Instead of insisting Taiwanese ownership of the Diaoyudao/ Senkakus, he now laid claim only to the continental shelf. While Taiwan did not recognize Japan's claim to the islands, Chiang's diaries reveal that he was willing to place the dispute over the ownership of the Diaoyudao/Senkakus in abeyance to open the door for international cooperation. ${ }^{18}$ His willingness to cooperate with Japan laid the groundwork for resolution of the vexing problem of overlapping interests on the continental shelf. ${ }^{19}$

In short, the dispute over the definition of the continental shelf and the ownership of the Diaoyu/Senkaku islands foreshadowed the uncertainty of future joint oil exploration between Japan, South Korea, and Taiwan. Also, while these countries implemented their own policies toward oil exploration in the East China Sea by themselves, they all had the same cooperative partner-the United States. The demand for capital and cutting-edge technology provided Washington with an opportunity to become involved in oil exploration in maritime East Asia - irrespective of the conflicts East Asian countries had among themselves.

While the geographical features of maritime East Asia resulted in several sovereignty-related disputes between Japan, South Korea, and Taiwan, they still expected to survey, research, and explore the natural resources of the continental shelf in the East China Sea jointly for mutual benefit. Of these three countries, Japan was the most enthusiastic in attempting to settle disputes over the overlapping claims to the continental shelf because of its location in the middle of controversial areas. Achieving a consensus with South Korea and Taiwan, for Tokyo, would solve the vexing deadlock over the continental shelf near the Diaoyu/Senkaku islands and the Kyūshū Nansei maritime area; otherwise, its maritime interests would be untenable. ${ }^{20}$ Facing this dilemma, Japan advocated that the three countries should cooperate mutually to explore the natural resources of the continental shelf at a non-government level, while ignoring the sensitive issue of ownership of the disputed islands, thereby allowing international collaboration without constant regression into contentious issues of ownership. ${ }^{21}$ Japan's unofficial approach provided an occasion to break the deadlock.

The Committee for Promotion of Japan-Taiwan Cooperation (Japan-Taiwan Committee), a quasi-non-governmental organization, accordingly provided a

\footnotetext{
18 Chiang Kai-shek diary entries, 11, 12, 14 September 1970, Chiang Kai-shek Diaries, Hoover Institution, Stanford University, Stanford, CA.

19 ROC MOFA statement, no date, 604.23/oo11, Zone V, DD, AIMH.

20 ROK-Japan Committee No. 1151, 12 October 1970, 604.23/ooo6, MOE, DD, ibid.

21 Express letter from Rос Embassy in Japan to ROC MоFA, 6 October 1970, ibid.
} 
paradigm for maritime East Asia to promote cooperation. Deputy Prime Minister of Japan Ishii Mitsujirō's visit to Taiwan in 1956 became the onset of the establishment of the Japan-Taiwan Committee. He proposed that it was necessary to organize a permanent quasi-non-governmental committee as an outpost to pave the way for future government-level negotiations. Such an unofficial approach would promote Japan-Taiwan collaboration in political, economic, and cultural aspects because it would secure agreement over issues prior to official negotiations. Ishii's mutually beneficial proposal drove both Taibei and Tokyo to establish the Japan-Taiwan Committee in $1957 .{ }^{22}$

The Japan-Taiwan quasi-non-governmental committee set a precedent in East Asia and this model also applied to the often-contentious Japan-Korea relationship. Despite both being unwavering allies of the United States, Japan and South Korea did not establish diplomatic relations until 1965 due to historical disputes, including the "Peace Line" on the sea. ${ }^{23}$ On 18 January 1952, Rhee Syngman, the first president of the Republic of Korea (вок), announced that Seoul reserved its rights on the Korean peninsula as well as on the continental shelf and seas near the contiguous zones of offshore islands, all of which were on average twenty miles out from shore. Rhee's claim caused widespread discontent in Tokyo not only because the "Peace Line" violated the principle of free navigation of the high seas and international fishing cooperation, but also because, more importantly, the Rhee administration demarcated Dokdo/ Takeshima within its "Peace Line," islands to which Japan also claimed ownership. Consequently, Rhee's "Peace Line" was a hurdle standing in the way of further maritime cooperation between Japan and South Korea. ${ }^{24}$

Seoul and Tokyo broke the deadlock following their signing of the Treaty on Basic Relations Between Japan and the Republic of Korea on 22 June 1965. South Korea also rescinded the "Peace Line" following the Japan-Korea Fishery Agreement, which not only demonstrated mutual agreement and cooperation on fishing affairs, but also proffered an occasion for further maritime cooperation. ${ }^{25}$ Similar to the Japan-Taiwan relationship, there was a need to have a

22 Regarding the details, see Sao-yang Hong, "Zhongri hezuo cejinhui dui Taiwan jingji jihua zhi cujin yu fazhan" ["The Committee for Promotion of Sino-Japanese Cooperation for Promotion and the Development of Economic Planning Taiwan"], Taiwan wenxian [Taiwanese Records] 63, no. 3 (2012): 91-124.

23 Shigeru Oda, Kaiyōhō no Genryū wo saguru: Kaiyō no kokusaihō kōzō [Exploration on the Origin of the International Law of the Sea: The Structure of Maritime International Law] (Tokyo: Yuushindoukoubunsha, 1989), 107-26.

24 Exchange of notes concerning co-operation on fisheries, 22 June 1965, S-0444-0014, Registry Section/Archives and Records Service/ogs [Office of General Services] Registry Archive Group-Legal [LE)], UNARMS.

Ibid. 
quasi-non-governmental committee as a mediator when Japan and South Korea addressed vexing political issues like maritime sovereignty. In 1969, Japan and Korea accordingly established the Committee for Promotion of JapanKorea Cooperation (Japan-Korea Committee) for natural resource exploration.

The establishment of two quasi-non-governmental committees provided maritime East Asian countries with an occasion to explore mutually these natural resources in the disputed areas. ${ }^{26}$ All agreed that the trilateral mutual exploration should hold the issue of ownership of continental shelf in abeyance and then should establish a joint venture to apply for exploration rights from relevant countries. ${ }^{27}$ Following trilateral coordination, the countries decided to form the Committee for Liaison of Sino-Japan-Korea Cooperation (JapanSouth Korea-Taiwan Liaison Committee) to discuss the execution of the mutual exploration project in the East China Sea. ${ }^{28}$ Following a meeting in Seoul and a second in Tokyo both during 1970, these three countries recognized that a single country could not supply cutting-edge technology, or afford the significant expenditure of maritime oil exploration. This mutual understanding drove these countries to achieve four points of consensus:

(1) Establishing an Asian Maritime Development Company to explore oil and other natural resources in the East China Sea jointly in order to eliminate any potential conflicts.

(2) Inviting American oil companies to participate in this international project due to American technology and capital.

(3) Putting the issue of sovereignty in abeyance.

(4) Assisting in negotiations on the sovereignty of the continental shelf between governments whenever necessary. ${ }^{29}$

This consensus created a clear picture of trilateral cooperation in maritime East Asia. These three countries established a Japan-South Korea-Taiwan Joint

26 Collection concerning Japan-Korea activities on the continental shelf of the East China Sea, no date, 604.23/0007, MOE, DD, AIMH.

27 Project concerning Sino-Japan-Korea Joint Maritime Exploration for the continental shelf of the East China Sea (Project), 2 October 1970, 604.23/ooo6, MOE, DD, AIM H; "Japan, Korea, and Taiwan jointly explore the continental shelf of the East China Sea," Asahi Shimbun [Asahi News] (Evening Edition), 25 September 1970.

28 Telegramme from Roc Embassy in Japan to ROC MOFA, 30 September 1970, 604.23/ooo6, MOE, DD, AIMH.

29 Sino-Japan Cooperation Committee No. 1151, 12 October 1970, ibid.; Telegramme from MOFA to ROC Embassy in the ROK, 3 November 1970, ibid.; "It is said that the ROC, Japan, and the Korea will implement a civil joint investment in order to resolve the disputes on the continental shelf," Zhongyang ribao [Central Daily News], 16 November 1970; "The Roc, Japan, and Korea discussed the oceanic development but did not touch on the issue of the Senkaku Islands," Zhongyang ribao, 6 March 1971. 
Ocean Exploration Committee at the end of 1970, which aimed to promote trilateral cooperation for surveying underwater natural resources, research, and development. Furthermore, the committee also established liaison offices in Taibei, Tokyo, and Seoul to strengthen the trilateral connection for future international cooperation. ${ }^{30}$ While things appeared to be on course and international cooperation for maritime natural resources in East Asia was close realization, dramatic changes in the international political arena suddenly quashed all the progress that had been made. As one of the largest of East Asian countries, the PRC could not be absent from this international project. But its involvement was complicated, and it played a crucial role in the eventual failure of international cooperation between Japan, South Korea, and Taiwan. The reasons for this were twofold-first, Japan's fear of a rising China, and second, the rapprochement between the United States and China in the 1970 .

In 1949, the Chinese civil war resulted in the creation of two Chinas-the PRC on mainland China and the Republic of China (ROC) on Taiwan. While Japan officially recognized, under Washington's pressure, the Chiang Kai-shek regime on Taiwan as the legitimate government of China, Beijing's sizable potential market still lured Japanese businessmen, which meant that Japan could not disconnect completely its business relationship with China. Japan hence took a two-sided policy toward the two Chinas, as it separated political and economic issues - this policy enabled Japan to have close business relationships with China at unofficial levels. ${ }^{31}$

As time passed, Beijing, as a rising power, gradually grew stronger and its return to the United Nations became inevitable at the end of the 196os. This changing international political structure also drove Mao Zedong, the chairman of the PRC, to take a hardline attitude toward political issues with the Satō Eisaku administration. It was not only because Satō maintained a stance of unwavering support for the Chiang Kai-shek regime on Taiwan, but also because he declared that the maintenance of South Korea's and Taiwan's security was essential to Japan's own security. In other words, Tokyo would share in Washington's responsibility for preserving regional security in the western Pacific. The PRC could not tolerate such close Japan-Taiwan connections, so it

30 A civil organization among the Roc, Japan, and Korea decided to speed up the continental shelf exploration project, 17 March 1971, 604.23/ooo8, MOE, DD, AIMH.

31 Regarding Japan's two-sided policy, see Ho Szu-shen, Baidang yu liangan zhijian: Zhanhou Riben duihua zhengce [Swaying between the ROC and the PRC: Japan's Postwar Policy toward China] (Taibei: Dongda Publisher, 1997). 
accused the Satō administration of reviving "Japanese militarism" which brought the China-Japan relationship to its lowest point. ${ }^{32}$

To force Japanese businessmen to choose a political side, Zhou Enlai, the premier of the PRC State Council, advanced his "Zhou's four principles" when Matsumura Kenzō, a Japanese businessman, visited China for the Japan-PRC trade memorandum in April 1970. Zhou insisted that China would not allow the establishment of commercial relations with four categories of Japanese companies:

(1) Any company which assists South Korea and Taiwan.

(2) Any company which invests in South Korea and Taiwan.

(3) Any company which supplies weapons and ammunition in support of U.S. policy toward the Vietnam War.

(4) Any company which is a subsidiary or an incorporated company of a U.S. company. ${ }^{33}$

Zhou even underscored the reasons for these limitations:

Be it friendly trade or trade memorandum, [all] must be based on the four principles. If anyone violates the principles, the Chinese government will disconnect business relationships-even if already under contract. We cannot associate ourselves with Japanese militarism. ${ }^{34}$

Zhou's four principles not only resulted in the erosion of the relationships Japan had built with South Korea and Taiwan, but also reduced the willingness of Japanese companies to partake in international cooperation projects in the East China Sea.

In addition to the rise of China, the maritime perception of American leaders also changed during the course of the Beijing-Washington rapprochement.

32 Masaya Inoue, Nicchu Kokkō Seijōka no Seijishi [A Political History of the Sino-Japanese Normalisation] (Nagoya: Nagoyadaigaku shuppankai, 2010), 402-403; Yoshimasa Miyazaki, Saishō Satō Eisaku [Prime Minister: Satō Eisaku] (Tokyo: Shin Sangyō Keizai Kenkyūkai, 1980), 165-66; "Satō Eisaku's daydream," Renmin ribao [People's Daily], 25 November 1964; "Satō Eisaku gives the America's imperialism huge help," Renmin ribao, 20 January 1965. Regarding the terms of Satō Eisaku's foreign policy, see Tzu-chin Huang, "Shouhui Liuqiu yu Zuotengrongzuo shouxiang de 'qinmeifangong' zhanlue" ["Prime Minister Sato Eisaku's Strategy of Okinawan Reversion: "Building the Nation Based on Pro-Americanism and Anti-Communism"], Yatai yanjiu luntan [Asia-Pacific Forum] 59 (December 2012): $1-48$.

33 Masaya, Nicchu Kokkō Seijōka no Seijishi, pp. 402-403.

34 Yongming Cheng and Qibao Shi, Zhongri jingmao guanxi liushinian [The Sixty Years of Sino-Japanese Trade Relations, 1945-2005] (Tianjin: Tianjin Shehui kexueyuan chubanshe, 2006), $15^{2}$. 
In the 1950s and 196os, U.S. policy-makers regarded the sea as one of the main frontiers to confront and contain the PRC. However, to end the Vietnam War, both President Nixon and National Security Advisor Henry Kissinger planned to seek rapprochement with Beijing and détente with Moscow to place pressure on North Vietnam to accept a reasonable basis for ending the Vietnam War. ${ }^{35}$ Under these circumstances, maritime space in East Asia appeared to serve not only as an occasion to demonstrate U.S. goodwill to the PRC, but also as a buffer to probe Beijing's political intentions in the western Pacific.

A measure of the goodwill the United States expressed toward the PRC was the termination by the end of the 1960s of its routine of having two destroyers patrol the Taiwan Strait. Kissinger intentionally leaked U.S. military redeployment in the Taiwan Strait to Beijing. ${ }^{36}$ Taiwan sensed that the American military commitment to it was changing, but the State Department explained the reasons for the termination of routine patrols as originating from fiscal issues and military redeployment (it reduced the use of over one hundred vessels). Also, the United States reassured that this change would not affect Washington's position in supporting Taibei.$^{37}$ Admiral John S. McCain Jr., the Commander of the Pacific Command, promised Chiang Ching-kuo, the vice president of Executive Yuan, that the United States still would patrol the Taiwan Strait but without a fixed schedule, and that there would be at least fifteen vessels monthly transiting the Taiwan Strait. ${ }^{38}$ Notwithstanding the U.S. promise to Taiwan, it was not hard to see that Washington's motivation behind this military redeployment was to avoid any conflict with the PRC at sea during the course of the rapprochement with Beijing.

Meanwhile, the changing international politics in East Asia reminded the United States that its golden age in maritime East Asia was slowly coming to an end. In January 1968, the Democratic People's Republic of Korea (DPRK) captured the uss Pueblo, a U.S. spy ship. Following a succession of negotiations,

35 Lien-Hang T. Nguyen, "The Soviet-Vietnamese Split and the Indochina War," in The Third Indochina War: Conflict between China, Vietnam and Cambodia, 1972-79, Odd Arne Westad and Sophie Quinn-Judge, eds. (London: Routledge, 2006), 19.

36 Yukinori Komine, Security in US Foreign Policy: Nixon, Kissinger and the Rapprochement with China (London: Routledge, 2016), 111.

37 Dialogue between Ji-zhuang Ma, Vice Minister of National Defense, and Vice Admiral John Chew, Commander of US Taiwan Defense Command, 17 November 1969, 005-010100ooo74-008, Sino-US Relations, vol. 2o, Collection of President Chiang Ching-kuo, Academia Historica [hereafter AH], Taipei, Republic of China.

38 Summary of talk concerning US navy patrolled the Taiwan Strait amongst Chiang Chi-kuo (Vice President of the Executive Yuan), David Packard (Deputy Secretary of Defense) and John S. McCain Jr. (Commander of the Pacific Command), 15 November 1969, 005-010206ooo86-013, Intelligence, Chiang Ching-kuo collection, AH. 
North Korea released the American crew, but Kim Il Sung, the first leader of the DPRK, retained the uss Pueblo and exhibited it as the spoil of war to demonstrate the "invasion of U.S. imperialism." ${ }^{39}$ The Uss Pueblo incident was just one of many symbols that challenged the U.S. maritime hegemony in East Asia. The PRC also was coming into its own on the international stage with the development of capabilities to intercept U.S. ships. Prior to the mid 196os, China's lack of naval strength only allowed it to condemn U.S. naval encroachment of its territorial waters verbally, such as "United States imperialists are stepping up their provocations along the coast of the Chinese mainland, seriously threatening the security of China." ${ }^{40}$ Even so, the United States rode roughshod over the Beijing's accusations. ${ }^{41}$ At the end of the 1960 s, the PRC began to intercept U.S. ships that purportedly had invaded its territorial waters. ${ }^{42}$ The intrusions of U.S. vessels' into China's territorial waters occurred during this time and the PRC gave the United States several serious warnings concerning its preservation of national sovereignty over maritime space. ${ }^{43}$ While the PRC was incapable of challenging American dominance in maritime East Asia, its successive harassment of U.S. vessels attracted Washington's attention and dragooned the United States into taking these events seriously thereafter.

At the same time, the willingness of Japan and Taiwan to put the disputed ownership of the continental shelf in abeyance did not resolve the issue of the Diaoyu/Senkaku islands; instead, it became increasingly tense. Between 1970 and 1971, Taiwanese non-governmental groups began a series of protests against Japan's claim on the ownership of the Diaoyudao/Senkakus. In September 1970, journalists from the China Times (Taiwan) not only placed Taiwan's national flag on the Diaoyu/Senkaku islands, but also painted Jiang zongtong wansui [Long live President Chiang] on the rocks. Japan regarded these actions as a provocation, and tore down the Taiwanese flag and expelled

39 Regarding the relationship between the uss Pueblo incident and U.S. foreign policy, see Mitchell B. Lerner, The Pueblo Incident: A Spy Ship and the Failure of American Foreign Policy (Lawrence: University Press of Kansas, 2002).

40 Addressed to Foreign Office telegram No. 499 of August 24, 24 August 1958, FO 371/133523, National Archives, London, UK.

41 United States Information Service, Taibei, Taiwan, Press Release, 12 September 1958, 633.16/oo12, International Law Commission [ILC], DD, AIMH.

42 "Chinese gunboats intercept American freighter," South China Morning Post, 29 October 1969.

43 Proposed cable to CINCPAC [Commander in Chief, Pacific] on $488^{\text {th }}$ and $489^{\text {th }}$ PRC [People's Republic of China] "Serious Warnings"-Action Memorandum, 9 April 1971, box 06, Subject Files of the Office of Asian Communist Affairs 1961-1973, Records of the U.S. Department of State, Record Group [RG] 59, National Archives II [hereafter NAII], College Park, MD. 
Taiwanese fishing boats from the area off the Diaoyudao/Senkakus. This was just one of the incidents illustrating the growing intensity of the Japan-Taiwan conflict over the Diaoyu/Senkaku islands. In the meantime, overseas Taiwanese relentlessly protested against Japan's retaliatory actions in regard to multiple incidents. Taiwanese scholars asserted that Taiwan should rebuff its participation in the international oil exploration project in the East China Sea until both sides reached a resolution regarding ownership of the Diaoyudao/ Senkakus. ${ }^{44}$

This deadlock led the United States, which both managed its hub-and-spoke alliance in East Asia and had oil exploration contracts with East Asian countries, to explicitly express its stance on international oil exploration projects because it did not want further complications, namely territorial disputes on the Diaoyudao/Senkakus between Japan and Taiwan, to arise. ${ }^{45}$ Following negotiations with Washington, the Gulf Oil Company, which operated near the Diaoyu/Senkaku islands, informed both Japan and Taiwan that, on account of the Japan-Taiwan dispute over the Senkaku islands, it would suspend all exploration in the area until Taipei and Tokyo reached a mutual agreement. ${ }^{46}$ Gulf's change in oil exploration operations near the Senkakus led Chiang Kai-shek to sense that the contour of international politics in maritime East Asia and Washington's China/Taiwan policies were changing. Taiwan was, as Chiang insisted, reluctant to see that its cooperation with the United States had come to a standstill since such cooperation was not only concerning numerous profits, but also related to its official relationship with the United States. Accordingly, in his diaries, Chiang stated that "we cannot abandon the Sino [Rос]-United States oil contracts," because he surmised that the termination of oil cooperation with U.S. companies would have far-reaching influence on international joint oil exploration projects with Japan and South Korea. ${ }^{47}$

As seen in subsequent historical developments, Chiang's assumption was correct-Gulf's suspension of operations was a prologue to the end of international cooperation between East Asian countries over oil exploration. After

44 Yu-ming Shao, Baodiao fengyunlu [Story of Defense of Diaoyutai] (Taibei: Lianjing chubanshe, 2013), 18; Robert Eldridge, The Origins of U.S. Policy in the East China Sea Islands Disputes, pp. 124-28; Tianshi Yang, Zhaoxun zhenshi de Chiang Kai-shek: Chiang Kai-shek Riji Jiedu [Seeking True Chiang Kai-shek: Interpretation of Chiang Kai-shek Dairies] (Hong Kong: Sanlian shudian, 2014), 340-41.

45 "U.S. backs Japan claim on Senkaku," Japan Times, 12 September 1970; Department of State spokesman Charles Bray response, "Maritime Oil Exploration and Diaoyutai" (Chinese translation), 29 April 1971, 604.23/ooo8, MOE, DD, AIMH.

46 Telegramme from Roc Embassy in Japan to MOFA, 26 November 1970, 604.23/ooo7, MOE, DD, AIMH.

Chiang Kai-shek diary entry, 7 December 1970, Chiang Kai-shek Diaries. 
Gulf's suspension of its oil exploration operations, Beijing's serious claim on natural resources near the Diaoyudao/Senkakus and Taiwan also impelled the United States to interject further on the collaborative project between Japan, South Korea, and Taiwan. Beijing could not allow other countries to explore the natural resources near its coasts and "territories," Taiwan in particular, because it viewed the Chiang Kai-shek regime in Taiwan as an illegal government that "had been abandoned by all Chinese people." ${ }^{48}$ It meant that all contracts with Taipei were illicit and already had encroached upon Beijing's sovereignty. The Chinese government thus strongly demanded that the collaborative project must cease immediately. ${ }^{49}$

The U.S. government could not ignore the PRC's unyielding attitude toward oil exploration because, it explained, the rise of China in East Asia "not only bears on the rules governing U.S. military, naval, and air activities in the China Seas, but also has implications in regard to U.S. commercial shipping and oceanographic survey activity." ${ }^{\prime 0}$ The decision makers in Washington realized that the joint oil exploration project related to the issue of sovereignty could spark an explosive conflict in the western Pacific, and that the sea would become a sensitive geographical space that easily triggered unwanted conflicts with the PRC. Herman Barger, the deputy assistant secretary of state for East Asian and Pacific Affairs, expressed his concerns when he met with representatives from major oil companies. He stressed that the PRC recently had sent the United States more severe notices than ever before in its claim to the resources of the Asian continental shelf. ${ }^{51}$ These warnings from Beijing were not merely in verbal/written forms as before. Washington was worried that the PRC's growing naval capabilities, especially air, surface, and submarine forces, could provide military support for its claim to control the natural resources of continental shelf. The PRC's harsh political language would have the potential to devolve into direct military confrontation in disputed maritime areas. ${ }^{52}$

48 "Another new offence against China and Korea, the American and Japanese reactionaries contrive to plunder China's and Korea's natural resources under seabed," Renmin ribao, 4 December 1970.

49 "[We] Cannot allow the American and Japanese reactionaries to plunder our resources of seabed," Renmin ribao, 29 December 1970.

$5^{0}$ Proposed cable to CINCPAC on $488^{\text {th }}$ and $489^{\text {th }}$ PRC "Serious Warnings"-Action Memorandum, 9 April 1971, Subject Files of the Office of Asian Communist Affairs 1961-1973, box 6, State Department Records, RG 59, NAII.

$5^{1}$ Warning to the Gulf oil company not to expect USG protection of its operation on Asian continental shelf, 10 January 1971, ibid.

52 Consideration by index geophysical of signing contract with China Petroleum Corporation to carry out seismic surveys in the East China Sea, 29 April 1971, ibid. 
As a corollary, the United States, in an attempt to avoid a worst-case scenario, dissuaded U.S. oil companies from drilling in sensitive areas near South Korea and Taiwan, which would provoke Beijing, but Washington still permitted explorations that U.S. oil companies operated in locations far from the disputed areas. ${ }^{53}$ In this way, the United States, as its wishful thought, simultaneously could maintain its relationship with the PRC and continue participating in oil projects in maritime East Asia. To request all American oil companies to adhere to its instructions, the State Department informed these companies that they no longer could depend on U.S. military protection during their operations in the concession zones in the Yellow and East China Seas, as well as the Taiwan Strait. ${ }^{54}$

In addition to displaying goodwill toward the PRC, security considerations also pushed the United States to interfere in international cooperation in maritime East Asia. Beijing considered the Gulflex - a survey ship with classified equipment, which was under contract to the Gulf Oil Company from the Ocean Science and Engineering Company - to be a Central Intelligence Agency (CIA) spy ship. The PRC's perception of the Gulflex reminded the United States of the embarrassing Pueblo incident, an experience it did not want to repeat. The Nixon administration accordingly made the decision to withdraw military protection and cancel licenses for the use of sensitive classified equipment to deter oil companies registered in the United States from pursuing their exploration projects in maritime East Asia. ${ }^{55}$

However, the oil companies, which had invested large amounts of money in these projects, did not comply with the U.S. government's wishes. The Gulf Oil Company argued, instead, that Washington should encourage a political settlement and thereby play a crucial role in the resolution of conflicting claims. Still, Barger noted that the United States was not in a position to draw any official median line in maritime East Asia. For the United States, the disputes between Japan and South Korea were manageable, but the disputes between

53 Selig Harrison, China, Oil, and Asia: Conflict Ahead (New York: Columbia University Press, 1977), 239.

54 Warning to the Gulf Oil Company not to expect USG [U.S. Government] protection of its operation on Asian Continental Shelf, 10 January 1971, Subject Files of the Office of Asian Communist Affairs 1961-1973, box 6, State Department Records, RG 59, NAII; Warning to Subclasses of Wendell Philips not to expect USG protection of their operations on Asian continental shelf, 5 February 1971, ibid.

55 Untitled, 5 April 1971, 604.23/ooo8, MOE, DD, AIM H; Warning to Clinton International not to expect USG protection of its operations on Asian Continental Shelf, 27 January 1971, Subject Files of the Office of Asian Communist Affairs 1961-1973, box 6, RG 59, NAII; Warning to Ocean Science and Engineering Company not to expect USG protection of its operations on Asian Continental Shelf, 10 February 1971, ibid. 
Beijing and Taibei were a more insoluble problem because each claimed sovereignty of the continental shelf on the grounds that it was the legitimate government of the whole of China. ${ }^{56}$

This vexing problem between China and Taiwan led the United States to distance itself from the troubled waters. It requested the Gulf Oil Company, which was working in "dangerous areas," to work in the east of Taiwan's Zone II or in South Korean waters instead of inside Zone II (Figure 1). The Gulf Oil Company followed Washington's instructions, but when it asked which areas were safe for oil exploitation, Barger responded that the State Department could not make binding decisions regarding ship movements for oil exploration in maritime East Asia. ${ }^{57}$ Barger's argument to dissuade the Gulf Oil Company from working in the "disputed area" was groundless, because a classified document from Taiwan's intelligence revealed that the "dangerous areas" the U.S. government identified were not dangerous as there were no PRC vessels there. ${ }^{58}$ It is clear that Washington noted the "dangerous areas" as an excuse to shift Gulf's working area away from Zone II to elsewhere with the underlying motive being not to provoke Beijing. Washington believed that only East Asian countries, and not the United States, could settle the disputes over exploration for natural resources. It therefore would not take any further measures until Beijing returned to the United Nations since it predicted that China's participation in the international community, particularly in the forthcoming 1973 UN maritime conference, would settle every vexing issue properly. Until that point, the U.S. government supposed that a moratorium would be the best course of action while the disputes continued. As a corollary, if American oil companies could implement the moratorium on their contractual obligations to South Korea and Taiwan, it would be the best resolution for them because it not only could avoid any trouble in contested waters, but also permit the companies to maintain their concession rights..$^{59}$

While the United States tactically delayed action when it suggested that American oil companies holding concessions in the disputed area postpone

56 Warning to United Geophysical Corporation not to expect USG protection of its operations on Asian Continental Shelf, 16 February 1971, Subject Files of the Office of Asian Communist Affairs 1961-1973, box 6, State Department Records, RG 59, NAII.

57 Operations of Gulfrex on North Asian continental shelf, 10 March 1971, ibid.

$5^{8}$ Record of dialogue concerning the United States government got involved in our maritime oil exploration between Zhang Shi-guang, Vice Minister of Economic Affairs and Mr Herman Barger, Deputy Assistance Secretary of State for East Asian and Pacific Affairs, undated, 604.23/0007, MOE, DD, AIMH.

59 Proposal that the Gulf Oil Corporation seek moratorium of its operations in North Asian continental shelf, 22 March 1971, Subject Files of the Office of Asian Communist Affairs 1961-1973, box 6, State Department Records, RG 59, NAII. 
their operations, this proposal was still unacceptable to South Korea and Taiwan. ${ }^{60}$ Washington's proposed solution was, for both of them, not only the economic but the political issue since U.S. goodwill toward the PRC seemed to undermine its commitment to the anti-Communist alliance. This goodwill in turn would create uncertainty regarding the international political structure. Both Seoul and Taibei expressed their dissatisfaction during Barger's visit to East Asia in April 1971. Both were unwilling to accept the moratorium for surveying and exploitation activities until all countries either settled all sovereignty-related disputes or created a feasible modus operandi, because they believed there was no simple solution to the continental shelf disputes. To maintain the existing cooperation with the United States, both of them warned Washington that they would cancel the concessions they had given if the American oil companies were unable to complete their stipulated obligations.

Considering the maintenance of relationships with South Korea and Taiwan, the U.S. government changed its mind and informed all American oil companies concerned that they still could fulfill their contractual obligations in the East China Sea, the Yellow Sea, and the Taiwan Strait, if they used nonsensitive equipment for navigation and measurement. Yet Washington discouraged oil companies from using U.S.-flagged ships with American crews in the course of oil exploration operations near the disputed areas. ${ }^{61}$ As a result, U.S. oil companies used Panamanian-flagged vessels without sensitive equipment and without American citizens on board. ${ }^{62}$

Washington's attempts to avoid conflict with Beijing led Tokyo to realize that further cooperative projects with Taibei would cause its relationships with the PRC and the United States to deteriorate. Accordingly, Japan sine die postponed its joint oil explorations with Taiwan in the Taiwan Strait and off the Diaoyu/Senkaku islands. ${ }^{63}$ Such action implied that Japan was going to abandon collaboration with Taiwan in the western Pacific, making Taiwan a sacrificial lamb in this political arena. ${ }^{64}$ Tanabe Yoshio, as a chief China analyst at the

6o Warning to Wendell Phillips Oil Company not to expect USG protection of its operations on North Asian continental shelf; Proposal that company seek moratorium of its operations there, 22 March 1971, Subject Files of the Office of Asian Communist Affairs 19611973, box 6, State Department Records, RG 59, NAII; Possible solutions to the problems presented by Chinese territorial claims East of Hong Kong, 17 May 1971, ibid.

$61 \quad$ Ibid.

62 Untitled, undated, Subject Files of the Office of Asian Communist Affairs 1961-1973, box 6, State Department Records, RG 59, NAII.

63 "Abandonment of Japan-Taiwan joint exploration for the oil under the Taiwan Strait," Yomiuri Shimbun [Yomiuri News], 12 March 1971.

64 Japan determined to leave the plan for oil exploration of seabed aside, 12 March 1971, 604.23/0008, MOE, DD, AIMH. 
Japanese Cabinet Research Office, provided a glimpse of the Japanese politicians' mindset in terms of oil exploration with Taiwan. He stated that "it would be easier to import oil directly from China than to invest money in the Diaoyudao/Senkakus or other parts of the shelf, so we would rather not excite the situation at this time." ${ }^{65}$ For Japan, potential markets and lucrative incentives in China were more important than acting in accordance with an anticommunism ideology.

Moreover, the Japanese believed that it was impracticable to settle the territorial issue without government-level negotiations and Japanese oil companies gradually lost their enthusiasm for cooperating with Taiwan. As a corollary, Yatsugi Kazuo, who had led the unofficial oil cooperation project, changed his mind in that he explicitly indicated that "we have had to enter into close relations with China in order to help China to keep a balance with the Soviets." 6 Thus, Takiguchi Takeo, director of the Japan Petroleum Exploration Company, who originally had intended to explore oil in the East China Sea, temporarily suspended his plan as a result of the changing international situation in response to Washington's appeal to avoid angering the PRC. ${ }^{67}$ The unofficial and official stance ended the Japan-Taiwan oil cooperation in the western Pacific. Tokyo froze all projects for natural-resource exploration off the Diaoyudao/ Senkakus at this juncture. Similarly, no Japanese oil company was willing to take a risk to invest in this politics-related project. This short-lived international cooperation between Japan, South Korea, and Taiwan thus came to end. ${ }^{68}$

By 1971, the international situation had changed dramatically in East Asia, both on land and at sea. The failure of the Chiang Kai-shek regime's defense of its claim to be China's representative at the United Nations was inevitable. On 25 October 1971, in accordance with UN General Assembly Resolution 2758, the PRC replaced the ROC (Taiwan) at the United Nations. Even though the United States maintained its diplomatic relations with the Taibei regime, the number of countries that had diplomatic ties with the ROC sharply dropped by 28 , from 66 to 38 between 1970 and 1973, including its formerly staunch ally Japan. ${ }^{69}$ Taibei not only lost its international legal status gradually, but also,

65 Quoted in Harrison, China, Oil, and Asia: Conflict Ahead, p. 167.

66 Quoted in ibid., p. 183.

67 Japan Petroleum Exploration Company suspended its oil exploration in the East China Sea, 26 April 1971, 604.23/ooo8, MOE, DD, AIMH.

68 Japanese Oil Development Company temporally stopped exploring oil in the East China Sea, 26 April 1971, ibid.

69 Regarding the details, see Cheng-ju Tu, Zhonghuaminguo zai Lianheguo de zuihou rizi [The Last Day of the Republic of China at the United Nations] (Taibei: Showwe, 2008). 
more importantly, it lost its ticket to the negotiating table of oil exploration in maritime East Asia.

The changed international situation in East Asia led to Taiwan's exclusion from the game of chess over oil exploration projects, but it did not mean an end to cooperation between Japan and South Korea. In fact, the exclusion of Taiwan simplified Japan-South Korea negotiations. The two countries held a succession of talks between 1971 and 1972; however, in terms of the delimitation of the continental shelf, the chasm between Tokyo's equidistance principle and Seoul's natural prolongation principle resulted in the failure of negotiations at the fifth Japan-Korea Periodical Ministerial Meeting in February $1972 .{ }^{70}$ The dispute over the demarcation of the continental shelf deriving from the Japan-South Korea-Taiwan joint international project thus remained unresolved.

Similar to the previous three-country negotiations, a quasi-non-governmental organization could serve as a mediator when the governmental tensions were high in the official relationship. The Japan-Korea Committee brought these two countries back to the negotiating table and provided them with an opportunity to make progress on some difficult bilateral issues. After the October 1972 Japan-Korea Periodical Ministerial Meeting, their experience of previous three-country negotiations made both sides realize that it would be necessary to settle the disputes over sovereignty through political negotiations if they wanted to jointly explore in the disputed areas. ${ }^{71} \mathrm{Kim}$ Sung-ku, the Director of the South Korean Foreign Ministry's Asian Affairs Bureau, optimistically indicated that this meeting was helpful as a new approach to settling the disputes in Korea's Zone 7 and a part of Zone 5 (Figure 2). ${ }^{72}$

The Japan-Korea talks entered a new phase in 1973. Kim Yong-sik, South Korean foreign minister, and Ōhira Masayoshi, his Japanese counterpart, had a meeting in April and exchanged opinions on the need to establish a new regional cooperative organization in the Asia-Pacific. Consequently, both sides drafted two agreements, one for natural resources exploration and exploitation and the other for the boundary demarcation of the continental shelf in

70 The process of conclusion, 26 February 1974, 604.23/oo11, Zone v, DD, AIMH; Junko Ando, "Nikkantairikudanakyōtei kōshō ni miru 'kyōdō rieki' kakuho no kokoromi” [“Attempt to pursue 'common interests' in the Agreement between Japan and Korea on the Continental Shelf negotiations"], Hokutōajia kenkyū [Shimane Journal of North East Asian Research] 27 (2016): 77 .

71 "Joint oil search issue may go to summit meet," The Korean Times, 8 October 1972, ; "Korea, Japan hold meet on joint probe of underwater oil," The Korea Times, 6 October 1972.

"Korea, Japan raise various problems," The Korea Times, 7 October 1972. 


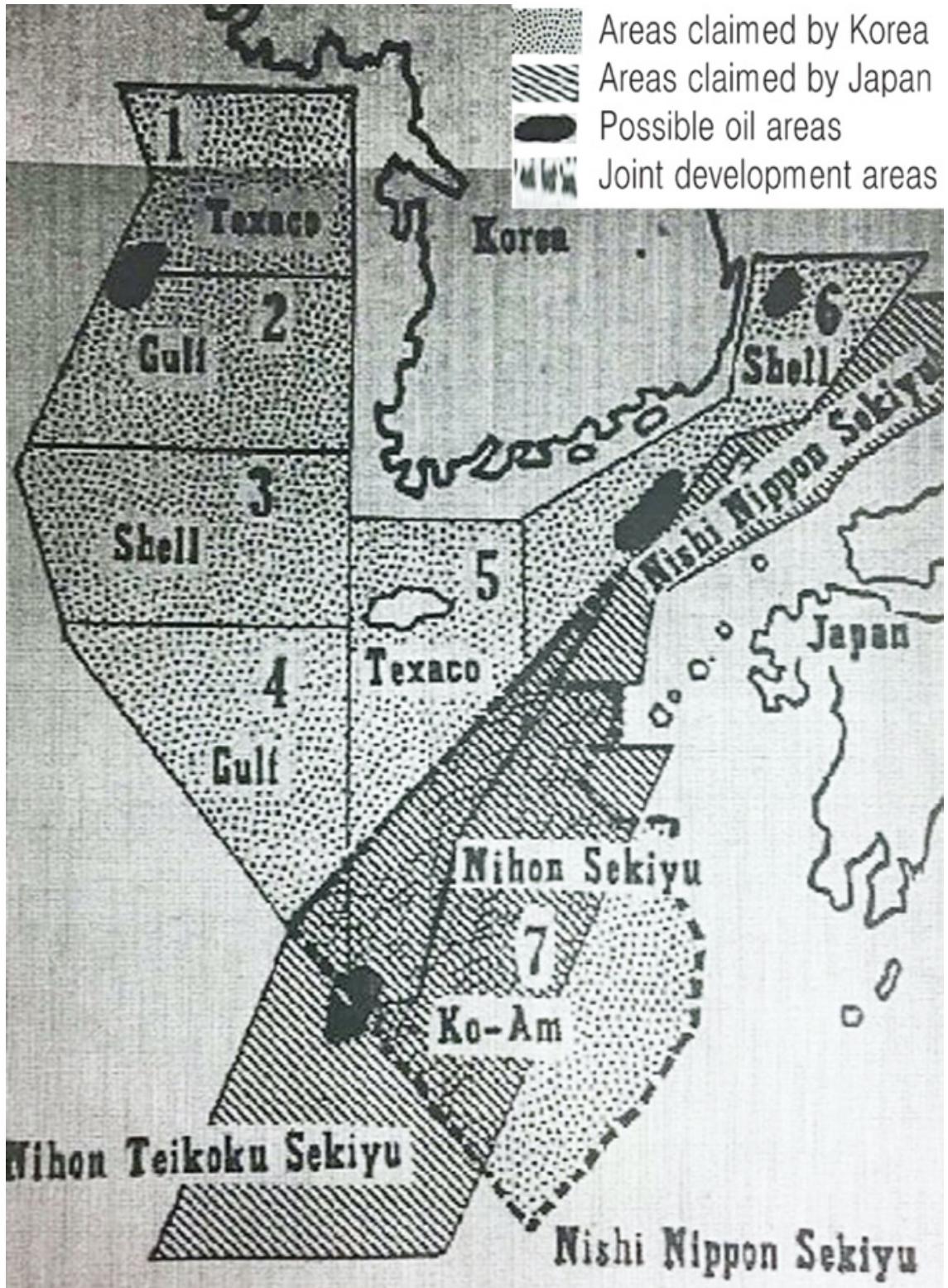

FIGURE 2 Japan-Korea Mutual Exploration zones

SOURCE: "KOREA, JAPAN ON OIL RESOURCES SEABED AGREEMENTS DRAFTED," 8 JULY 1973, THE KOREA HERALD 
the Korea Strait. ${ }^{73}$ While this was a negotiation between Japan and South Korea, Taiwan could not afford to be a bystander because the Japan-South Korea agreements not only might affect Taiwan's Zone v, but also infringe on Taibei's claim on the natural resources of the continental shelf. ${ }^{74}$ For this reason, Taiwan contrived to obtain the records of the Tokyo-Seoul negotiations from pro-Taiwanese Korean officials, but its efforts were in vain. Taiwan's exclusion from these negotiations signified that the Roc had lost all its influence in this chess game and the new international politics of maritime East Asia dislocated it from center to periphery in terms of oil exploration. ${ }^{75}$

Subsequent incidents led to a deteriorating Japan-Korea relationship, postponing the signing of the Northern Part Agreement and the Southern Part Agreement. ${ }^{76}$ The first incident was the 1973 RоK government's kidnapping of Kim Dae-jung. In 1973, the Korean Central Intelligence Agency (KCIA) abducted Kim, who was a leader of the opposition movement against Pak Chŏng-hŭi's leadership in South Korea when Kim visited Tokyo. This kidnapping quickly destroyed Japan-South Korea relations because the Japanese government regarded the abduction in Tokyo that the KCIA planned as a violation of Japan's sovereignty. ${ }^{77}$

The kidnapping of Kim Dae-jung was not the end but the prologue to a worsening Japan-Korea relationship. In August 1974, the assassination of Yuk Yŏngsu, South Korea's first lady, further aggravated deteriorating Japan-South Korea relations and delayed the signing of the bilateral agreements. Her killer was Mun Se-gwang (Nanjō Seikō), an ethnic Korean in Japan (zainihon chosenjin), who was attempting to murder President Pak Chŏng-hŭi. Pak dodged the bullet, but his wife was not so fortunate. Mun's bullets not only cost Yuk Yŏngsu's life, but also shattered already fragile Japan-South Korea relations

73 "Kim, Ohira agree on oil search pact, mull new Asia body," Korean Times, 17 April 1973; "Korea, Japan on oil resources seabed agreements drafted," Korea Herald, 8 July 1973.

74 Record of conference on discussion about Korea-Japan joint oil exploration in the East China Sea, 6 November 1973, 604.23/oo11, KJMEZ, DD, AIMH.

75 Express letter from Roc Embassy in Korea to ROC MOFA, 17 March 1972, ibid.

$7^{6}$ The full names of these two agreements are (1) the Agreement between Japan and the Republic of Korea Concerning the Establishment of Boundary in the Northern Part of the Continental Shelf Adjacent to the Two Countries and (2) the Agreement Concerning Joint Development of the Southern Part of the Continental Shelf Adjacent to the Two Countries.

77 "The process of conclusion: Joint oil drilling to start Soon Korea, Japan sign pacts on sea shelf," The Korea Herald, 31 January 1974. Regarding the Korean Central Intelligence Agency's kidnapping of Kim Dae-jung, see Eisuke Nakazono, Rachi: Shirarezaru Kindai chū jiken [Abduction: Unknown Kim Dai-jung Incident] (Tokyo: Shinchosha, 2002). 
because Mun held a Japanese passport. Seoul censured Tokyo for its ineffectual investigation of the assassination and its thoughtlessness in regard to Mun's Japanese citizenship. ${ }^{78} \mathrm{~A}$ relentless anti-Japanese sentiment became widespread in South Korea. This worsened the Japan-Korea relationship and led to the RoK National Assembly to postpone its ratification of the two agreements. The Japanese counterparts adopted the same measure in retaliation until 1978 when the Japan-Korea relationship improved as a result of U.S. efforts to promote reconciliation. ${ }^{79}$

The signing of the Japan-Korea Northern/Southern Part Agreements isolated the PRC from international cooperation in maritime East Asia again, but Beijing could not allow such a lucrative project to proceed without its participation. After the PRC replaced the ROC as China's representative at the United Nations, it began to take a more forceful stance on international affairs, including toward its neighboring countries. For instance, Beijing not only fiercely argued that flagrant U.S.-Korea drilling activities in the Yellow Sea and the East China Sea infringed upon its sovereignty, but also boldly claimed that all natural resources of the continental shelf extended from the Asian continent belonged to the Chinese government. ${ }^{80}$ The PRC further asserted that the JapanKorea agreements already had encroached upon China's sovereignty because they did not negotiate with all countries involved prior to exploring the natural resources. ${ }^{81}$

Beijing's verbal protests revealed that it was still in a weak position to explore the natural resources of the continental shelf on its own. While the PRC was on the threshold of significant progress between the shallow waters of the Pohai Gulf and other close-in areas, it was incapable of exploring the deep waters of the continental shelf. Even so, Beijing did not want to forgo participation in these international cooperative endeavors, associated as they were with questions of sovereignty and the economic benefits from potential oil reserves. ${ }^{82} \mathrm{~A}$ few months after the signing of the Japan-Korea relations Northern/ Southern Part Agreements, Beijing requested Tokyo to re-negotiate the issue with other interested governments, including the PRC and North Korea.

${ }_{78}$ For details, see Koui Kana, Ware, Daitōryō o Uteri [IShoot the President] (Tokyo: Kadensha, 2016).

79 Junko Ando, "Nikkantairikudanakyōtei kōshō ni miru 'kyōdō rieki' kakuho no kokoromi," pp. $83-84$.

8o The latest news, 16 March 1973, 602.6/ooo1, Overlapping of ROC-Korea Continental Shelf, DD, AIMH.

81 Communist bandits protested against the Japan-Korea agreements on continental shelf, 6 February 1974, 020000005161A, Japan-Korea Relations, Chiang Ching-kuo collection, AH. Harrison, China, Oil, and Asia: Conflict Ahead, p. 82. 
However, Japan rejected the proposal because it realized that the purpose of Beijing's remonstration was to clarify its stance and reserve its rights for future negotiations on the issue. ${ }^{83}$ Since the PRC had little influence on Japan-South Korea agreements, it saw that its "verbal protest" was not as effective as on the case of the Taibei-Tokyo-Seoul joint oil exploration projects. Beijing's warnings could not push Washington into involvement in matters concerning oil exploration again this time because the vexing player: Taiwan — which could trigger an all-out conflict between China and the United States - was out of this international chess game. Washington's new policy of non-interference in the Japan-South Korea Northern/Southern Part Agreements limited the PRC's claim on the natural resources of the continental shelf to a verbal formality.

This article has argued that natural resources management was an epitome of changing political interactions between the United States and its allies in the western Pacific from a non-military position. Sovereignty, local interests, and Washington's international security concerns, as this research shows, constituted the dynamic scenario that played on the restless arena in maritime East Asia. At the end of the 196os, the UN-led exploitation projects showed that the possibility of abundant oil reserves in the East China Sea, and this "possibility" launched the conflicts between Japan, South Korea, and Taiwan. The need of East Asian countries for capital and technology brought the United States to maritime East Asia and allowed American oil companies to explore in the areas that they claimed. However, the disputes between these countries developed over their mutual claims on the ownership of the continental shelf. To break this deadlock, they put the disputes over sovereignty in abeyance to allow for them to mutually explore these resources in an unofficial way, which was the first time that nations carried out an international cooperation in maritime East Asia.

While events appeared to be on course and international cooperation for exploiting maritime natural resources in East Asia was close to realization, dramatic changes in the international political arena suddenly quashed all recent progress. The rise of the PRC pushed the United States to participate in this chess game, which resulted in the failure of Japan-Korea-Taiwan joint oil exploration projects. Concretely, Beijing's interception of U.S. ships navigating in Chinese territorial waters led the United States to realize that the PRC's protests were no longer merely verbal/written warnings, but that these

83 Communist bandits requested Japan to negotiate the issue of continental shelf, 27 June 1974, 020000005310A, Interaction between Japan and Communist Bandit, Chiang Chingkuo collection, $\mathrm{AH}$. 
could devolve into military confrontation. As a corollary, the United States changed its perception of maritime space in East Asia. Washington supposed that the sea would be a dangerous geographical space that might trigger an all-out conflict with the PRC. It not only cancelled routine patrolling in the Taiwan Strait, but also became actively involved in this vexing chess game. Washington began to regard the maritime space of East Asia as a buffer zone for keeping a distance from the enemy, instead of a geostrategic barrier for containment.

Washington's unwillingness to take any risks that could impede its rapprochement with Beijing revealed that maritime space in East Asia served as a geographical space for the United States to signal its goodwill to the PRC. Accordingly, the United States not only explicitly proclaimed that its naval forces would not protect American oil companies which worked in disputed areas, it also forced oil companies to implement a moratorium on exploration and research. The decision makers' deliberations obviously aimed to avoid new conflicts during the course of Beijing-Washington rapprochement. Such U.S. involvements accelerated the breakdown of Japan-Korea-Taiwan joint exploration project. Without Taiwan, Japan and Korea could complete their own agreements on the continental shelf in the previous disputed area and their exclusive negotiations also relocated Taiwan from center to periphery in the search for new energy sources. This international chess game in maritime East Asia saw that the reserves and whereabouts of oil beneath the continental shelf of the East China Sea would not be protagonists in this scenario; the meaning of this game performed on the sea was to provide the relevant countries with opportunities different from those found on land to illustrate the actual concerns of these actors that were often hidden behind diplomatic language. These international joint oil exploration projects in the East China Sea provides the necessary historical lens to understand the contours of the shifting geopolitical structure during the 1970s in maritime East Asia.

\section{Acknowledgements}

I would like to thank Professor Andrew Preston, Professor Barak Kushner, Dr Mujeeb Khan, and Dr Sherzod Muminov for their helpful comments and suggestions on the earlier drafts of this article. I would also like to express my sincere gratitude to Professor Fumiko Nishizaki, Professor Shin Kawashima, Dr Bi-Yu Chang. They kindly gave me opportunities to share some parts of this research at the University of Tokyo and soAs, London. Dr Hao Wang also generously shared the Chiang Kai-Shek and Chiang Ching-Kou documents with me. No words can truly express how grateful I am. 


\section{Bibliography}

\section{Primary Sources}

"Abandonment of Japan-Taiwan joint exploration for the oil under the Taiwan Strait." Yomiuri Shimbun, 12 March 1971.

Archive of Institute of Modern History. Academia Historica. Taibei, Taiwan.

Chiang Kai-shek Diaries. Hoover Institution. Stanford University. Palo Alto, CA.

"Chinese gunboats intercept American freighter." South China Morning Post, 29 October 1969 .

Collection of Chiang Ching-kuo. Academia Historica. Taibei, Taiwan.

"Deposit is sought in East China Sea: Oil is sought in the Far East." New York Times, 17 May 1969, pp. 43, 51 .

"It is said that the ROC, Japan, and the Korea will implement a civil joint investment in order to resolve the disputes on the continental shelf." Zhongyang ribao [Central Daily News], 16 November 1970.

"Japan, Korea, and Taiwan jointly explore the continental shelf of the East China Sea." Asahi Shimbun [Asahi News] (Evening Edition), 25 September 1970.

"Japan will press efforts to exploit major oil find." New York Times, 1 September 1969, p.2. Korean Times, October 1972.

Kokkai kaigi-roku kensaku shisutemu [System for the Legislative Record of the Diet]. http://kokkai.ndl.go.jp.

"Korea, Japan on oil resources seabed agreements drafted." Korea Herald, 8 July 1973.

"The process of conclusion: Joint oil drilling to start Soon Korea, Japan sign pacts on sea shelf." The Korea Herald, 31 January 1974.

National Archives. London, UK.

National Archives Administration. Taibei, Taiwan.

Richard M. Nixon. "Statement about United States Ocean Policy," 23 May 1970. Chapter Six: Oceans Policy. Foreign Relations of the United States, 1969-1976, Volume E-1, Documents on Global Issues, 1969-1972, https://2001-2009.state.gov/r/pa/ho/frus/nixon/ e1/53194.htm.

Renmin ribao [People's Daily], November 1964-December 1970.

"The ROC, Japan, and Korea discussed the oceanic development but did not touch on the issue of the Senkaku Islands." Zhongyang ribao [Central Daily News], 6 March 1971.

"Convention on the Continental Shelf." Socioeconomic Data and Applications. https:// sedac.ciesin.columbia.edu.

"U.S. backs Japan claim on Senkaku." Japan Times, 12 September 1970.

U.S. Department of State. Records of the U.S. Department of State. Record Group 59. National Archives II. College Park, MD.

United Nations Archives and Records Management Section. United Nations. New York, NY. 


\section{Secondary Sources}

Ando Junko. "Nikkantairikudanakyōtei kōshō ni miru 'kyōdō rieki' kakuho no kokoromi" ["Attempt to pursue 'mutual interests' in the Agreement between Japan and Korea on the Continental Shelf negotiations]. Hokutōajia kenkyū [Shimane Journal of North East Asian Research] 27 (2016): 71-86.

Blanchard, Jean-Mark F. "The US Role in the Sino-Japanese Dispute over the Diaoyu (Senkaku) Islands, 1945-1971." China Quarterly 161 (March 2000): 95-123.

Ceng Hong-zhi. "Woguo haiyu shiyou kuangqu zhi huali ji waizi canyu hezuo tanyou" ["The Delimitation of Taiwan's Maritime Oil Mining Zones and Cooperation Survey with Foreign Investments"]. Kuangye [Mining and Metallurgy] 56, No. 3 (September 2012): 11-21.

Cha, Victor Cha. Powerplay: The Origins of the American Alliance System in Asia. Princeton, NJ: Princeton University Press, 2016.

Chen, Kuan-jen. "U.S. Maritime Policy in Cold War East Asia, 1945-1979." Unpublished Ph.D. Dissertation. University of Cambridge 2019. Cambridge, UK.

Cheng Tao. "The Sino-Japanese Dispute Over the Tiao-yu-tai (Senkaku) Islands and the Law of Territorial Acquisition." Virginia Journal of International Law 14, No. 2 (Winter 1974): 221-66.

Cheng Yongming and Shi Qibao. Zhongri jingmao guanxi liushinian [The Sixty Years of Sino-Japanese Trade Relations, 1945-2005]. Tianjin: Tianjin Shehui kexueyuan chubanshe, 2006.

Eldridge, Robert D. The Origins of the Bilateral Okinawa Problem: Okinawa in Postwar US-Japan Relations, 1945-1952. New York: Garland, 2001.

Eldridge, Robert D.. The Origins of U.S. Policy in the East China Sea Islands Disputes: Okinawa's Reversion and the Senkaku Islands. London: Routledge, 2013.

Emery, Kenneth, et al. "Geological Structure and Some Water Characteristics of the East China Sea and Yellow Sea." Technical Bulletin 2 (1969): 3-43.

Harrison, Selig. China, Oil, and Asia: Conflict Ahead. New York: Columbia University Press, 1977 .

Ho Szu-shen. Baidang yu liangan zhijian: Zhanhou Riben duihua zhengce [Swaying between the ROC and the PRC: Japan's Postwar Policy toward China]. Taibei: Dongda Publisher, 1997.

Hong Sao-yang. "Zhongri hezuo cejinhui dui Taiwan jingji jihua zhi cujin yu fazhan" ["The Committee for Promotion of Sino-Japanese Cooperation for Promotion and the Development of Economic Planning Taiwan"]. Taiwan wenxian [Taiwanese Records] 63 No. 3 (2012): 91-124.

Huang Tzu-chin. "Shouhui Liuqiu yu Zuotengrongzuo shouxiang de 'qinmeifangong' zhanlue" [Prime Minister Sato Eisaku's Strategy of Okinawan Reversion: Building the Nation Based on Pro-Americanism and Anti-Communism"]. Yataiyanjiu luntan [Asia-Pacific Forum] 59 (December 2012):1-48. 
Ikenberry, Gilford John. "American hegemony and East Asian order." Australian Journal of International Affairs 58, No. 3 (2004): 353-67.

Inoue Masaya. Nicchu Kokkō Seijōka no Seijishi [A Political History of the Sino-Japanese Normalisation]. Nagoya: Nagoyadaigaku shuppankai, 2010.

Ji, Guoxing. "Sino-Japanese Jurisdictional Delimitation in East China Sea." In Maritime Boundary Dispute, Settlement Process, and the Law of the Sea. Seoung-Yong Hong and Jon M. Van Dyke, eds., 77-106. Leiden, Netherlands: Martinus Nijhoff Publishers, 2009.

Kana Koui. Ware, Daitōryō o Uteri [I Shoot the President]. Tokyo: Kadensha, 2016.

Karaman, Igor V. Dispute Resolution in the Law of the Sea. Leiden, Netherlands: Martinus Nijhoff, 2012.

Kawashima, Shin. "The Origins of the Senkaku/Diaoyu Islands Issue." Asia-Pacific Review 20, No. 2 (2013): 122-45.

Komine, Yukinori. Security in US Foreign Policy: Nixon, Kissinger and the Rapprochement with China. London: Routledge, 2016.

Lerner, Mitchell B. The Pueblo Incident: A Spy Ship and the Failure of American Foreign Policy. Lawrence: University Press of Kansas, 2002.

Nakazono Eisuke. Rachi: Shirarezaru Kindai chü jiken [Abduction: Unknown Kim Daijung Incident]. Tokyo: Shinchosha, 2002.

McCune, Shannon. Islands in Conflict in East Asian Waters. Hong Kong: Asian Research Service, 1984 .

Miyazaki Yoshimasa. Saishō Satō Eisaku [Prime Minister: Satō Eisaku]. Tokyo: Shin Sangyō Keizai Kenkyūkai, 1980.

Nguyen, Lien-Hang. "The Soviet-Vietnamese split and the Indochina War." In The Third Indochina War: Conflict between China, Vietnam and Cambodia, 1972-79. Odd Arne Westad and Sophie Quinn-Judge, eds., 12-32. London: Routledge, 2006.

Oda Shigeru. Kaiyōhō no Genryū wo saguru: Kaiyō no kokusaihō kōzō [Exploration on the Origin of the International Law of the Sea: The Structure of Maritime International Law]. Tokyo: Yuushindoukoubunsha, 1989.

Park, Choon-Ho. "Oil Under Troubled Waters: The Northeast Asia Sea-Bed Controversy." Harvard International Law Journal 14, No. 2 (Spring 1973): 218-20.

Park, Hee Kwon. The Law of the Sea and Northeast Asia: A Challenge for Cooperation. Leiden, Netherlands: Martinus Nijhoff, 2000.

Shao Yu-ming. Baodiao fengyunlu [Story of Defense of Diaoyutai]. Taibei: Lianjing chubanshe, 2013.

Tu Cheng-ju. Zhonghuaminguo zai Lianheguo de zuihou rizi [The Last Day of the Republic of China at the United Nations]. Taibei: Showwe, 2008.

Yang Tianshi. Zhaoxun zhenshi de Chiang Kai-shek: Chiang Kai-shek Riji Jiedu [Seeking True Chiang Kai-shek: Interpretation of Chiang Kai-shek's Dairies]. Hong Kong: Sanlian shudian, 2014. 